\title{
Ratana (Ischaemum indicum, Houtt; sin. I. Ciliere, Retz) response to intensive management under different nitrogen fertilization rates in the Humid Tropics
}

\author{
Milton Villarreal-Castro ${ }^{1 \dagger}$, Edin Villalobos ${ }^{1}$, Carlos Rodriguez ${ }^{1}$, Ernesto Ducca ${ }^{2}$ and \\ Olger Alfaro ${ }^{2}$
}

\begin{abstract}
${ }^{1}$ Escuela de Agronomía, Instituto Tecnológico de Costa Rica, Sede San Carlos. Alajuela, Costa Rica; ${ }^{2}$ Ministerio de Agricultura y Ganadería. Dirección Regional Huetar Norte, Costa Rica
\end{abstract}

\begin{abstract}
Introduction
Ischaemum indicum is a forage grass used mainly under grazing systems that was introduced in Costa Rica more than 40 years ago. Since then, this species has been predominant in the Humid Tropic's conditions, as an introduced grass or as a volunteer species invading improved pastures. I. indicum presents well developed propagation systems through "true seeds" and vegetative material. Despite those characteristics, I. indicum has shown some constrains when intensive management is required. During the 'less' rainy season, profuse flowering and low vegetative growth are the main characteristics of Ratana pastures. During the rainy season, it is susceptible to some pest such as "spittlebogs" and "chinche" somehow limiting its forage yield (Villarreal, 1992). Ratana pastures can be seen as a degradation stage of highly productive pastures based on grasses such as Cynodon nlemfuensis, Brachiaria sp., and others, or as the last option for those conditions in which higher productive species cannot be introduced because economic, technical or farmer's preference situations. Regardless of how Ratana becomes a dominant species, high forage yield should be the goal for those dairy and beef farms that have this species in their pastures. Strategic fertilization use to achieve intensive and sustainable pasture management is considered common practice. Nitrogen fertilization has been recognized as one of the factors exerting major impact on pasture maintenance and productivity (Spain and Gualdrón, 1988). However, it is uncertain if Ratana responds to nitrogen fertilization. There is lack of information about how Ratana performs when nitrogen is provided and how it interacts with different regrowth ages (Villarreal and Bustamante, 1996).

For that reason ongoing research is being carried out in the Humid Tropic of Costa Rica to consider if Ratana-based pastures are a possible option for intensive management systems.
\end{abstract}

\section{Methodology}

Four different Ratana pastures locations were chosen, corresponding to different farms distributed in the Huetar Norte Region. In each farm, an experiment with the same characteristics was set. Twelve treatments (factorial treatment design: 4 Nitrogen levels $\times 3$ regrowth ages; 0, 150, 300, and $450 \mathrm{~kg} \mathrm{~N} / \mathrm{ha} / \mathrm{yr}$, and 4, 6, and 8 weeks regrowth age) were randomly assigned into three blocks in a complete block design with $2 \times 3 \mathrm{~m}$ size plots. Forage samples using a $0.5 \times 1 \mathrm{~m}$ size frame were taken by mechanical clipping at $5 \mathrm{~cm}$ above ground level according to regrowth age. Then, the whole plot was cut to a uniform height (same as sampling height) and residual material was taken out of the plots. Nitrogen fertilization was applied immediately after sampling according to each treatment. Forage samples were partly dried in a forced-air oven at $55^{\circ} \mathrm{C}$ for $96 \mathrm{hr}$ and partial dry matter content was measured after samples equilibrated with environmental humidity. When necessary, samples were manually separated into Ratana and volunteer species. After 24 weeks of the experiment, botanical composition was visually estimated. Six, 4, and 3 sampling events have been taken corresponding to 4, 6, and 8-week regrowth age, respectively. Forage biomass data (kg DM/ha/cutting) was analyzed using the MIXED procedure of SAS with DDFM $=$ KR option with block as random effect in the model. The LSMEANS/PDIFF option was used to generate treatment means and mean comparisons. The linear, quadratic, and cubic effect of nitrogen fertilization were evaluated using the CONTRAST option of the MIXED procedure specifying the corresponding coefficients for equally spaced treatments.

\section{Results \& Discussion}

So far the results for a global analysis (4 locations) suggest the effects of nitrogen, regrowth age, and location $\times$ regrowth age interaction. There was a discrete linear increase $(P=0.0001)$ in DM yield as nitrogen fertilization increased, although in two of the four locations tested the quadratic trend also fits. Average DM yield were 1625, 2074, 2071, and $2279 \mathrm{~kg} \mathrm{DM} / \mathrm{ha}$ for 0, 150, 300, and $450 \mathrm{~kg} \mathrm{~N} / \mathrm{ha} / \mathrm{yr}$, respectively. The effect of regrowth age shows a linear increase $(P=0.0001)$ in DM yield. Average values across nitrogen levels were 1351, 2088, and $2672 \mathrm{~kg} \mathrm{DM} / \mathrm{ha} /$ cutting for 4, 6, and 8 week regrowth age, respectively. Even though DM yields seem to be high (growth rate of $48 \mathrm{~kg}$ DM/ha/ day, approximately $17.5 \mathrm{t} \mathrm{DM} / \mathrm{ha} / \mathrm{yr}$ ) it is important to point out that with the exception of one location, there has been a general dropping in forage production over time. Defoliation frequency and intensity, and pest damages (Blissus sp., Hemipter:Lygaeidae and Aeneolamia sp., Homopter:Cercopidae) have been key factors in such performance. Additional evaluation during the 'less' rainy season completing a 1-year research period will help to better understand the Ratana potential response to nitrogen fertilization under different harvesting frequencies as a strategy of find out if this grass can be used in a more intensive way in the humid tropics grazing systems.

† E-mail: miltonvillarreal@yahoo.com 


\title{
References
}

Spain JM and Gualdron R 1988. Degradación and rehabilitación de pasturas. In Establecimiento and renovación de pasturas (eds C. Lascano and J. Spain), pp. 269-283. RIEPT. Sexta Reunión del Comité Asesor. CIAT, Cali, Colombia.

Villarreal CM 1992. Evaluación comparativa de Ratana (Ischaemum indicum) como especie forrajera. Agronomía Costarricense 16, 37-44.

Villarreal CM and Bustamante L 1996. Respuesta del pasto Ratana (Ischaemum indicum) a la fertilización nitrogenada. Memoria X Congreso Nacional Agronómico and de Recursos Naturales, III Congreso Nacional de Fitopatología, II Congreso Nacional de Suelos. Vol. 3.San José, Costa Rica. EUNED, EUNA. pp. 165.

\section{Effect of the volatile fraction from sugarcane silage and forage inclusion on the ruminal $\mathrm{pH}$, redox potential, temperature, and partial pressure of $\mathrm{H}_{2}$ on beef cattle diets}

\author{
João Luiz Pratti Daniel, Luiz Gustavo Nussio ${ }^{\dagger}$, Vanessa Pilon Santos, Janaína Rosolem Lima, \\ Adir de Sá Neto, Gisele Bonato Muraro and Bruna Cortes Queiroz
}

University of São Paulo, ESALQ, Dept of Animal Science, Brazil

\section{Introduction}

Ensiling sugarcane leads to the conversion of water soluble carbohydrates to fermentation products, which are well characterized by high levels of volatile organic compounds, such as ethanol. Some ruminal parameters of bovine fed sugarcane silages are found in the literature (Schmidt et al., 2007), nevertheless, there is a poor understanding of how the fermentation products from sugarcane silage may affect physico-chemical aspects of the rumen fluid. The main goal of this study was to determine whether volatile fermentation end products from silage and the forage:concentrate ratio may affect the ruminal $\mathrm{pH}$, redox potential $\left(\mathrm{E}_{\mathrm{h}}\right)$, temperature, and partial pressure of $\mathrm{H}_{2}\left(\mathrm{PH}_{2}\right)$ in beef cattle diets.

\section{Material and methods}

Six Nellore beef steers were randomly assigned to a replicated $3 \times 3$ Latin square design with 14 -d period. Steers were housed in a tie-stall barn, and individually fed ad libitum daily at $0800 \mathrm{~h}$. Dietary treatments were balanced to reach isonitrogen content: 75D (dry) - 75\% sugarcane silage without volatile fraction (dried at $60^{\circ} \mathrm{C}$ and re-hydrated) and $25 \%$ concentrate, $75 \mathrm{~W}$ (wet) - $75 \%$ wet sugarcane silage and $25 \%$ concentrate, and $40 \mathrm{~W}$ (wet) $-40 \%$ wet sugarcane silage and $60 \%$ concentrate (DM basis). On day 11 of each period, before feeding time, data loggers (temperature sensors) were placed into the ventral sac of the rumen to record the temperature every 30 minutes over $24 \mathrm{~h}$. Rumen $\mathrm{pH}$ and redox potential were measured every two hours on day 13 in anaerobic conditions. The redox potential was calculated as $E_{h}=E_{0}+199$, where $E_{0}$ is the potential of the platinum electrode $(m V)$. The $\mathrm{PH}_{2}(a t m)$ was calculated based on Nernst's equation using pH and $E_{h}$ values (Marden et al., 2009). Data were compared as repeated measurements over time using the MIXED procedure of SAS. Orthogonal contrasts were used for specific comparisons: $75 \mathrm{D}$ versus $75 \mathrm{~W}$ to test the volatile fraction effect, and $75 \mathrm{~W}$ vs $40 \mathrm{~W}$ to test the forage:concentrate ratio effect. Pearson correlations among variables were performed by using the CORR procedure.

\section{Results}

The volatile fraction from sugarcane silages (mean value of 19\% DM from wet silages) did not alter the ruminal parameters studied. However, changes in forage:concentrate ratio affected all the studied variables. The lower forage inclusion (75W vs $40 \mathrm{~W})$ increased rumen $E_{h}(-97$ vs $-64 \mathrm{mV} ; P<0.01)$ and temperature $\left(38.7\right.$ vs $\left.39.5^{\circ} \mathrm{C} ; P<0.01\right)$, and reduced $\mathrm{PH}_{2}\left(4.6 \mathrm{vs} 1.9 \times 10^{10} \mathrm{~atm} ; P=0.08\right)$. However, the $40 \mathrm{~W}$ diet led to a higher $(P<0.01) \mathrm{DM}$ intake (not shown). There was interaction between Diet and Time for rumen $\mathrm{pH}(P<0.01)$ although rumen $\mathrm{pH}$ has been lower for diets with less forage. $E_{h}$ showed a significant correlation with all of the variables and $\mathrm{pH}$ was not correlated with $\mathrm{PH}_{2}$.

Table 1 Pearson correlation coefficients and probability for slope among rumen $\mathrm{pH}, \mathrm{E}_{h}, \mathrm{PH}_{2}$, and temperature

\begin{tabular}{lrrr}
\hline & $\mathrm{E}_{\mathrm{h}}$ & \multicolumn{1}{c}{$\mathrm{Ph}_{2}$} & \multicolumn{1}{c}{ Temperature } \\
\hline $\mathrm{Ph}$ & $-0.63(P<0.01)$ & $0.05(P=0.44)$ & $-0.51(P<0.01)$ \\
$\mathrm{E}_{\mathrm{h}}$ & & $-0.58(P<0.01)$ & $0.47(P<0.01)$ \\
$\mathrm{Ph}_{2}$ & & $-0.20(P<0.01)$ \\
\hline \hline
\end{tabular}

\footnotetext{
${ }^{\dagger}$ E-mail: nussio@esalq.usp.br
} 